\title{
ANALISIS PROFITABILITAS PADA PERUSAHAAN FOOD AND BEVERAGES YANG TERDAFTAR DI BURSA EFEK INDONESIA TAHUN 2015-2018
}

\author{
Randy Alifianda $^{1^{*}}$, Nurjanti Takarini ${ }^{2}$ \\ ${ }^{12}$ Fakultas Ekonomi dan Bisnis, UPN "Veteran" Jawa Timur, Surabaya \\ *Penulis Korespondensi; ${ }^{1}$ randyalifianda@gmail.com, ${ }^{2}$ yayannurjanti@yahoo.com
}

\begin{abstract}
The company was founded with the aim of getting maximum and sustainable profits. Profitability can be used to assess how well a company can survive in its business. So, the purpose of this research was to find out the effect of liquidity, leverage, and activities in increasing profitability. The sample selection technique used in this research was purposive sampling. Samples obtained were 17 food and beverage companies listed on the Indonesia Stock Exchange in the 2015-2018 period. The data used in this research were secondary data obtained from the Indonesia Stock Exchange. The data analysis technique used in this research was multiple linear regression analysis. Based on the results of research that had been investigated, it can be concluded that leverage calculated using Debt to Assets Ratio was not able to contribute to profitability. Liquidity calculated using Current Ratio and Activities calculated using Total Assets Turnover Ratio can contribute to profitability.
\end{abstract}

Keywords: Profitability, current ratio, debt to assets ratio, total assets turnover ratio.

\section{Pendahuluan}

Profitabilitas pada suatu perusahaan menjadi sorotan yang pertama kali dilirik oleh investor, calon kreditur, pemilik perusahaan, dan manajemen perusahaan. Profitabilitas mendeskripsikan kapabilitas suatu perusahaan dalam menghasilkan profit melalui seluruh kekuatan yang dipunyai dari pihak yang berkepentingan. Bagi pemimpin perusahaan, profitabilitas dipakai untuk menjadi ukuran atas keberhasilan perusahaan yang dinahkodainya. Profitabilitas perusahaan diharapkan dapat meningkat setiap periodenya dengan melihat beberapa elemen keuangan pada perusahaan.

Bursa Efek Indonesia yaitu sebuah pasar ekuitas yang bisa dipakai opsi pendanaan bagi seluruh sektor perusahaan di Indonesia khususnya untuk sub sektor food and beverages. Menurut Kementerian Perindustrian tahun 2019, selama tahun 2018, perusahaan food and beverages dapat tumbuh sebesar $7,91 \%$ atau melewati pertumbuhan ekonomi nasional di angka 5,17\%. Berkembangnya perusahaan food and beverages merupakan hal yang penting karena sub sektor ini masih menjadi andalan untuk menopang pertumbuhan ekonomi nasional. Peran krusial sub sektor ini tampak dari partisipasinya yang stabil dan berarti terhadap PDB atau produk domestik bruto (www.kemenperin.go.id).

\section{Tabel 1}

Rata-Rata Profitabilitas (ROA) Perusahaan Food and Beverages yang Terdaftar di BEI Tahun 2015-2018

\begin{tabular}{ccc}
\hline Alat Ukur & Tahun & Rata-Rata \\
\hline & 2015 & $6,16 \%$ \\
Profitabilitas & 2016 & $5,75 \%$ \\
(ROA) & 2017 & $6,35 \%$ \\
& 2018 & $5,72 \%$ \\
\hline
\end{tabular}

Sumber: www.idx.co.id (data diolah)

Berdasarkan data pada Tabel 1 mengindikasikan bahwa rata-rata profitabilitas pada 25 perusahaan food and beverages dari periode 2015 sampai 2018 menunjukkan hasil fluktuatif dari tahun ke 
tahun. Ketika tahun 2018, perusahaan sub sektor makanan dan minuman mengalami penurunan angka ROA yang menunjukkan adanya masalah pada profitabilitas.

Terdapat beberapa faktor yang mampu membuat profitabilitas perusahaan menurun, diantaranya adalah faktor likuditas, leverage, dan aktivitas. Variabel likuiditas menurut Horne dan Wachowicz (2013) menjelaskan ketika perusahaan dipertemukan dengan masalah dengan adanya pertukaran antara faktor likuiditas dan profitabiltas. Jika perusahaan mencapai kesepakatan menetapkan ekuitas dengan kuantitas yang banyak dapat menyebabkan likuiditas perusahaan ikut tinggi pula akan tetapi peluang dalam memperoleh laba berpotensi kecil. Kedua, dipilihnya variabel leverage menurut Riyanto (2013) perusahaan dipertemukan dengan persoalan penetapan sumber keuangan. Pembiayaan dari pihak luar atau dengan memakai utang bisa berdampak pada angka leverage suatu perusahaan. Jika leverage perusahaan mengalami kenaikan akan berakibat pada menurunya nilai profitabilitas perusahaan. Terakhir, dipilihnya variabel aktivitas menurut Hery (2015) yaitu rasio yang dikenakan untuk menilai keefektifan pendayagunaan sumber daya yang dipunyai oleh suatu perusahaan. Rasio ini berfungsi mengukur seberapa efektif perusahaan memanfaatkan aset mereka untuk mendapatkan pendapatan. Semakin besar aktivitas menandakan semakin efektif ketika mengelola aset untuk mendapatkan penjualan netto.

\section{Kajian Teoritis dan Hipotesis Profitabilitas}

Profitabilitas yaitu rasio yang dipakai guna menganalisis kinerja perusahaan pada saat memperoleh keuntungan pada tahun yang ditentukan. Menurut Sartono (2014) menjelaskan bahwa profitabilitas yaitu kekuatan perusahaan mendapatkan keuntungan ketika berhubungan dengan penjualan netto, aset, dan ekuitas. Target perusahaan ialah dapat mencapai profit yang diinginkan supaya mempunyai peluang bisa memaksimalkan kekayaan bagi pihak yang berkepentingan.

Dalam riset ini menggunakan rasio Return on Assets (ROA) untuk alat hitung dari profitabilitas karena Return on Assets memberikan pengertian tentang kapabilitas perusahaan pada saat mendapatkan keuntungan dengan memakai aset yang dipunyai. Semakin besar nilai ROA menandakan bertambah banyak profit yang didapatkan dari penggunaan semua aset dalam kegiatan perusahaan, sehingga berdampak pada manajemen yang menjalankan perusahaan menjadi lebih efektif dan efisien.

\section{Likuiditas}

Likuiditas yaitu rasio guna menilai kapabilitas perusahaan pada saat melunasi semua utang lancarnya ketika jatuh tempo dengan memakai aset lancar yang tersedia (Syamsuddin, 2016). Bagi pihak eksternal perusahaan, seperti kreditor, investor, distributor, dan masyarakat umum, rasio likuiditas berguna sebagai alat hitung kapabilitas perusahaan ketika melunasi utang pada kelompok yang bersangkutan.

Dalam riset ini menggunakan Rasio Lancar (Current Ratio) untuk alat hitung dari likuiditas dikarenakan Current Ratio memberikan penjelasan perihal kekuatan perusahaan dalam melunasi utang lancar atau utang yang akan jatuh tempo ketika ditagih. Kemudian Horne dan Wachowicz, (2013) menyatakan bahwa adanya perbandingan terbalik antara profitabilitas dengan likuiditas.

\section{Leverage}

Menurut Kasmir (2013) menjelaskan bahwa rasio leverage yaitu rasio yang dikenakan untuk menghitung berapa besar aset perusahaan yang ditanggung dengan utang. Dalam pengertian cakupan besar dijelaskan ketika leverage dipakai guna menilai kapabilitas perusahaan saat memakai aset dan dana yang berbasis utang untuk upaya merealisasikan tujuan perusahaan demi memaksimalkan kekayaan pemilik perusahaan.

Dalam riset ini memakai Debt to Assets Ratio (DAR) sebagai komponen dari leverage karena Debt to Assets Ratio memberikan penjelasan perihal kemampuan perusahaan dalam menilai berapa besar dampak utang perusahaan kepada pendayagunaan kekayaan milik perusahaan berupa asetnya. Rasio leverage dengan angka besar bisa berakibat munculnya efek kerugian yang cukup tinggi, oleh karenanya tidak menutup kemungkinan bisa berkesempatan memperoleh keuntungan yang lebih tinggi (Kasmir, 2013). 


\begin{abstract}
Aktivitas
Menurut Hery (2015) mengungkapkan bahwa rasio aktivitas yaitu rasio yang dikenakan untuk menilai keefektifan atas penggunaan sumber daya yang dipunyai suatu perusahaan. Rasio aktivitas bertujuan menghitung efisiensi perusahaan ketika memakai aset yang dipunyainya dan guna melihat kapabilitas perusahaan saat menjalankan aktivitas setiap harinya (Kasmir, 2013).

Dalam riset ini menggunakan Total Assets Turnover Ratio (TATO) untuk alat hitung dari aktivitas karena Total Assets Turnover Ratio memberikan penjelasan perihal kapabilitas aset suatu perusahaan dalam mendapatkan penjualan netto. Semakin besar Total Assets Turnover Ratio menandakan perusahaan semakin efisien ketika menggunakan asetnya demi memperoleh penjualan netto.
\end{abstract}

\title{
Pengaruh Likuiditas terhadap Profitabilitas
}

\section{Pengembangan Hipotesis}

Menurut Horne dan Wachowicz (2013) menyatakan bahwa adanya perbandingan terbalik antara profitabilitas dengan likuiditas. Angka likuiditas yang cukup besar berakibat kurang baik kepada perolehan keuntungan dikarenakan adanya dana yang menganggur atau menandakan terlalu banyak modal kerja yang diperlukan, efek ini dapat membuat turun peluang dalam mendapatkan laba (Riyanto, 2013). Felany dan Worokinasih (2018) dalam risetnya menemukan bahwa likuiditas yang dihitung memakai Current Ratio mempunyai pengaruh dengan arah positif serta signifikan terhadap Return on Assets. Kondisi itu menjelaskan ketika perusahaan mempunyai Current Ratio besar akan mendapatkan ROA yang besar pula. Angka Current Ratio yang besar menunjukan ketersediaan aset lancar guna melunasi utang jangka pendeknya juga besar. Berdasarkan pendapat diatas maka dapat dihipotesiskan seperti berikut:

Hipotesis 1: Likuiditas berpengaruh dengan arah positif terhadap profitabilitas.

\section{Pengaruh Leverage terhadap Profitabilitas}

Leverage yang besar dapat menyebabkan munculnya efek kerugian yang cukup tinggi, akan tetapi perusahaan masih ada kesempatan memperoleh keuntungan lebih tinggi (Kasmir, 2013). Pada riset yang dijalankan Marusya dan Magantar (2016) menemukan bahwa leverage yang dihitung memakai Debt to Assets Ratio mempunyai pengaruh dengan arah negatif serta signifikan terhadap Return on Assets. Keadaan itu menjelaskan bahwa perusahaan yang mempunyai nilai DAR besar cenderung mempunyai ROA yang kecil, dan begitu juga sebaliknya. Utang yang bertambah dapat mengakibatkan biaya kebangkrutan yang cukup tinggi daripada melakukan hemat pajak dari beban bunga utang atas kewajiban, oleh karenanya dapat membuat turun kinerja keuangan perusahaan yang dihitung menggunakan ROA. Berdasarkan pendapat diatas maka dapat dihipotesiskan seperti berikut:

Hipotesis 2: Leverage berpengaruh dengan arah negatif terhadap profitabilitas.

\section{Pengaruh Aktivitas terhadap Profitabilitas}

Aktivitas memperlihatkan kemampuan aset suatu perusahaan pada saat mendapatkan penjualan netto. Semakin besar rasio Total Assets Turnover Ratio menandakan perusahaan itu semakin efisien pada saat menggunakan asetnya demi memperoleh penjualan netto. Rahma, Cipta, dan Yudiaatmaja (2016) dalam risetnya menemukan bahwa aktivitas yang dihitung menggunakan Total Assets Turnover Ratio mempunyai pengaruh dengan arah positif serta signifikan terhadap Return on Assets. Hal tersebut menyatakan bahwa jika penjualan naik, maka profit akan naik pula. Aktiva suatu perusahaan dipengaruhi oleh tinggi rendahnya pendapatan. Berdasarkan pendapat tersebut dapat dihipotesiskan seperti berikut:

Hipotesis 3: Aktivitas berpengaruh dengan arah positif terhadap profitabilitas.

\section{Metode Penelitian}

Variabel yang dipakai pada riset ini, yaitu:

1. Profitabilitas $(Y)$

Profitabilitas yaitu kapabilitas perusahaan pada saat memperoleh laba tahun berjalan dari akivitas yang dijalankan dalam tahun yang ditentukan (Brigham \& Houston, 2013). Indikator profitabilitas 
yang dikenakan pada riset ini yaitu Return on Assets. Menurut Brigham dan Houston (2013) rumus profitabilitas seperti di bawah:

\section{Likuiditas $\left(X_{I}\right)$}

$$
\text { Return on Assets }=\frac{\text { Laba Bersih }}{\text { Total Aset }} \times 100 \%
$$

Dalam riset ini indikator dari likuiditas yang dipakai yaitu rasio lancar (Current Ratio) ialah rasio yang berfungsi untuk menghitung kapabilitas perusahaan dalam melunasi utang lancar atau utang yang akan jatuh tempo ketika ditagih secara keseluruhan. Menurut Horne dan Wachowicz (2013) rumus Current Ratio seperti berikut:

\section{Leverage $\left(X_{2}\right)$}

$$
\text { Current Ratio }=\frac{\text { Aktiva Lancar }}{\text { Utang Lancar }}
$$

Dalam riset ini indikator dari leverage yang dipakai yaitu rasio total hutang terhadap total aktiva atau Debt to Assets Ratio (DAR) adalah rasio yang berfungsi untuk menghitung berapa besar aset perusahaan yang ditanggung dengan utang. Menurut Kasmir (2013) rumus Debt to Assets Ratio seperti berikut:

\section{Aktivitas $\left(X_{3}\right)$}

$$
\text { Debt to Assets Ratio }=\frac{\text { Total Utang }}{\text { Total Aktiva }} \times 100 \%
$$

Dalam riset ini indikator dari aktivitas yang dipakai adalah rasio perputaran total aktiva atau Total Assets Turnover Ratio (TATO) yaitu salah satu rasio aktivitas yang menilai efektivitas penggunaan seluruh aset perusahaan untuk menunjang penjualan. Menurut Munawir (2014) rumus Total Assets Turnover Ratio sebagai berikut:

$$
\text { Total Assets Turnover Ratio }=\frac{\text { Penjualan }}{\text { Total Aktiva }}
$$

\section{Populasi dan Sampel Penelitian}

Populasi pada riset ini yaitu industri makanan dan minuman yang tercatat di BEI tahun 20152018. Jumlah populasi dari perusahaan tersebut adalah 25 perusahaan. Teknik pemilihan sampel yang dipakai yaitu purposive sampling. Dari 25 perusahaan hanya diambil 17 perusahaan makanan dan minuman yang tercatat di BEI periode 2015-2018 berlandaskan kriteria yang sudah ditetapkan.

\section{Tabel 2}

\section{Hasil Pemilihan Sampel}

\begin{tabular}{lc}
\multicolumn{1}{c}{ Keterangan } & $\begin{array}{c}\text { Jumlah } \\
\text { Perusahaan }\end{array}$ \\
\hline $\begin{array}{l}\text { Perusahaan food and beverages yang terdaftar di Bursa Efek Indonesia tahun } \\
\text { 2015-2018. }\end{array}$ & 25 \\
$\begin{array}{l}\text { Perusahaan food and beverages yang melakukan penawaran umum perdana } \\
\text { (IPO) di Bursa Efek Indonesia pada periode 2015-2018. }\end{array}$ & 6 \\
$\begin{array}{l}\text { Perusahaan food and beverages yang di akuisisi atau mengalami transisi } \\
\text { manajemen dan tidak memiliki data penelitian yang dibutuhkan. }\end{array}$ & 2 \\
Jumlah sampel penelitian & 17 \\
\hline
\end{tabular}

Berdasarkan kriteria pada Tabel 2, sampel yang bisa dipakai untuk bahan riset yaitu 17 industri makanan dan minuman. Kemudian dikalikan dengan empat tahun periode riset yaitu mulai 20152018. Jadi, total terdapat 68 unit data observasi (17 x 4) dalam riset ini.

\section{Metode Analisis Data}

Teknik analisis data yang dipakai pada riset ini yaitu dengan analisis regresi linier berganda dengan metode kuantitatif dan bantuan software SPSS 24 for Windows. 


\section{Analisis Data dan Pembahasan \\ Uji Outlier}

Outlier adalah data yang memiliki karakteristik khas dan kelihatan berbeda sekali dari data riset yang lainnya (nilai ekstrim). Terdapat outlier apabila Mahal. Distance Maximum > Prob. dan Jumlah variabel $[=\mathrm{CHIINV}(0,001 ; 4)$ : dicari melalui Excel $]=18.467$. Namun dalam riset ini Nilai Mahal. Distance Maximum 16,685 yang lebih kecil dari 18,467 berarti tidak ditemukan outlier pada data itu, oleh karenanya data itu memiliki kualitas yang baik dan bisa dipakai untuk diolah lebih dalam lagi.

\section{Uji Normalitas}

\section{Uji Asumsi Klasik}

Normalitas adalah sebuah model regresi yang variabel terikat dan bebas atau keduanya memiliki distribusi normal atau tidak. Diperoleh hasil analisis bahwa variable CR $\left(X_{I}\right)=0,000$, DAR $\left(X_{2}\right)=$ 0,001 dan TATO $\left(X_{3}\right)=0,003$, sehingga tidak berdistribusi normal karena signifikasinya lebih kecil dari 0,05 . Berdasarkan "central limit of theorem" jumlah data yang diolah termasuk data besar, yaitu lebih dari 30. Dengan demikian dapat diasumsikan bahwa data dianggap berdistribusi NORMAL (Sekaran, 2006).

\section{Uji Multikolinieritas}

Multikolinieritas adalah uji yang berfungsi untuk mengetahui adanya korelasi variabel bebas pada regresi berganda. Dalam pengujian multikolineritas terhadap analisis regresi linier berganda ini menjelaskan bahwa untuk variabel CR $\left(X_{1}\right)=1,686$, DAR $\left(X_{2}\right)=1,692$, dan TATO $\left(X_{3}\right)=1,014$, tidak menandakan adanya gejala multikolinieritas yang ditunjukkan nilai VIF pada variabel lebih kecil dari 10 (Cryer \& Miller, 1994).

\section{Uji Heteroskedastisitas}

Heteroskedastisitas adalah uji yang dipakai untuk melihat varian dari residual dari satu pengamatan ke pengamatan yang lainnya mempunyai varian berbeda. Hasil analisis menyatakan bahwa pada variabel CR $\left(X_{1}\right)=0,410$, DAR $\left(X_{2}\right)=0,802$, dan TATO $\left(X_{3}\right)=0,957$, tidak memiliki korelasi yang signifikan antara residual dengan variabel independennya, dan nilai signifikansi tiap-tiap variabel $>0,05$, sehingga bisa ditarik kesimpulan bahwa tidak terjadi Heteroskedastisitas dan seluruh variabel penelitian memenuhi asumsi Heteroskedastisitas.

\section{Uji Autokorelasi}

Autokorelasi adalah uji yang dipakai untuk melihat adanya korelasi antara kesalahan pengganggu pada periode $t$ dengan kesalahan pengganggu periode $t$-1 (sebelumnya). Jika data di atas 15 (catatan: Autokorelasi pada sebagian besar data time series). Untuk asumsi klasik yang mendeteksi adanya autokorelasi di sini tidak dilakukan karena data bukan data time series. Jika uji autokoreasi tetap dilakukan, maka untuk asumsi klasik yang mendeteksi adanya autokorelasi di sini menunjukkan hasil bahwa nilai Durbin Watson sebesar 1,751 (Posisi angka diantara -2 sampai +2 tidak ada autokorelasi), kondisi itu menunjukkan tidak terdapat gejala autokorelasi.

Jadi bisa ditarik kesimpulan bahwa model regresi linier berganda yang didapatkan dalam riset memenuhi asumsi klasik.

\section{Hasil Regresi Berganda}

Analisis regresi linier berganda yang dipakai pada riset ini untuk melihat kekuatan variabel bebas dalam menjelaskan variabel terikat dianalisis dari koefisien determinasi $\left(R^{2}\right)$. Dengan demikian dijelaskan hasil analisis regresi seperti berikut:

Berdasarkan angka konstanta dan koefisien regresi pada Tabel 3, maka hubungan antara variabel bebas dan variabel terikat dalam model regresi seperti berikut:

$\mathrm{ROA}=\beta_{0}+\beta_{1} \mathrm{CR}+\beta_{2} \mathrm{DAR}+\beta_{3} \mathrm{TATO}+\mu_{i}$ $\mathrm{ROA}=-7,290+2,852 \mathrm{CR}+0,111 \mathrm{DAR}+3,877 \mathrm{TATO}+\mu_{i}$ 
Tabel 3

Hasil Perhitungan Nilai Koefisien Regresi Linier Berganda

\begin{tabular}{|c|c|c|c|c|c|c|c|c|}
\hline \multirow{2}{*}{ Model } & \multicolumn{2}{|c|}{$\begin{array}{c}\text { Unstandardized } \\
\text { Coefficients }\end{array}$} & \multirow{2}{*}{$\begin{array}{c}\text { Standardized } \\
\text { Coefficients }\end{array}$} & \multirow[b]{2}{*}{$t$} & \multirow[b]{2}{*}{ Sig. } & \multirow{2}{*}{$\begin{array}{c}\text { Correlations } \\
\text { Partial }\end{array}$} & \multicolumn{2}{|c|}{$\begin{array}{c}\text { Collinearity } \\
\text { Statistics }\end{array}$} \\
\hline & $B$ & $\begin{array}{l}\text { Std. } \\
\text { Error }\end{array}$ & & & & & $\begin{array}{l}\text { Toler } \\
\text { ance }\end{array}$ & $V I F$ \\
\hline (Constant) & -7.290 & 5.859 & & -1.244 & .218 & & & \\
\hline$X_{l}=\mathrm{CR}$ & 2.852 & .952 & .438 & 2.996 & .004 & .351 & .593 & 1.686 \\
\hline$X_{2}=\mathrm{DAR}$ & .111 & .092 & .177 & 1.207 & .232 & .149 & .591 & 1.692 \\
\hline$X_{3}=$ TATO & 3.877 & 1.908 & .230 & 2.032 & .046 & .246 & .987 & 1.014 \\
\hline
\end{tabular}

a. Dependent Variable: $Y=$ ROA

\section{Uji Hipotesis}

a. Uji Parsial (Uji $t)$

1. CR $\left(X_{I}\right)$ berpengaruh dengan arah positif dan (nyata) terhadap ROA $(Y)$, atau bisa diterima dengan tingkat [Sig. 0,004 $<0,05$ : signifikan dengan arah positif.

2. DAR $\left(X_{2}\right)$ tidak berpengaruh positif dan (tidak nyata) terhadap ROA $(Y)$, atau tidak bisa diterima dengan tingkat [Sig. 0,232>0,05: tidak signifikan dengan arah positif.

3. TATO $(X 3)$ berpengaruh dengan arah positif dan (nyata) terhadap ROA $(Y)$, atau bisa diterima dengan tingkat [Sig. $0,046<0,05$ : signifikan dengan arah positif.

\section{b. Uji Simultan (Uji F)}

\section{Tabel 4}

Hasil Perhitungan Uji Simultan

\begin{tabular}{llccccc}
\hline & Model & Sum of Squares & $d f$ & Mean Square & $F$ & Sig. \\
\hline 1 & Regression & 1571,420 & 3 & 523,807 & 4,989 &, $004^{\mathrm{b}}$ \\
& Residual & 6719,312 & 64 & 104,989 & & \\
& Total & 8290,733 & 67 & & & \\
\hline
\end{tabular}

a. Dependent Variable: $Y=$ ROA

b. Predictors: (Constant), $X_{3}=$ TATO, $X_{1}=\mathrm{CR}, X_{2}=$ DAR

Berdasarkan hasil dari Tabel 4 diperoleh $F_{\text {hitung }} 4,989$ (uji kecocokan model) ini menunjukkan hasil yang signifikan dengan tingkat signifikan 0,004 maka bisa ditarik kesimpulan bahwa alat analisis regresi berganda yang dipakai sebagai alat analisis ini cocok atau bisa dipakai sebagai alat analisis. Terlihat dari angka $F_{\text {hitung }}=4,989$ dengan Sig. $0,004<0,05:$ signifikan positif, dengan demikian perubahan ketiga variabel CR $\left(X_{1}\right)$, DAR $\left(X_{2}\right)$, dan TATO $\left(X_{3}\right)$, mampu menjelaskan perubahan variabel $\operatorname{ROA}(Y)$.

\section{c. Uji $R$ Square}

\section{Tabel 5}

Hasil Perhitungan Uji R Square

\begin{tabular}{|c|c|c|c|c|c|c|c|}
\hline \multirow[b]{2}{*}{ Model } & \multirow[b]{2}{*}{$R$} & \multirow[b]{2}{*}{ R Square } & \multirow[b]{2}{*}{$\begin{array}{c}\text { Adjusted } R \\
\text { Square }\end{array}$} & \multirow[b]{2}{*}{$\begin{array}{l}\text { Std. Error of } \\
\text { the Estimate }\end{array}$} & \multicolumn{2}{|c|}{ Change Statistics } & \multirow[b]{2}{*}{ Durbin-Watson } \\
\hline & & & & & $\begin{array}{c}R \text { Square } \\
\text { Change }\end{array}$ & $\begin{array}{l}\text { Sig. } F \\
\text { Change }\end{array}$ & \\
\hline 1 & $435^{\mathrm{a}}$ & 190 & 152 & 10,24643 &, 190 & 004 & 1,751 \\
\hline
\end{tabular}

a. Predictors: (Constant), $X_{3}=$ TATO, $X_{1}=\mathrm{CR}, X_{2}=$ DAR

b. Dependent Variable: $Y=$ ROA 
Berdasarkan hasil dari Tabel 5 diperoleh nilai koefisien determinasi $\left(R^{2}\right)$ sebesar 0,190 atau 19\% yang berarti variabel independen dapat menjelaskan variabel dependen sebesar $19 \%$ sedangkan sisanya $81 \%$ [100\% - 19\%] diterangkan oleh variabel yang lain selain variabel CR $\left(X_{1}\right)$, DAR $\left(X_{2}\right)$, serta TATO $\left(X_{3}\right)$. Hasil ini mendeskripsikan adanya hubungan yang rendah antara variabel bebas secara simultan dengan variabel terikat.

\section{Pembahasan}

Berdasarkan hasil yang telah diteliti dapat dinyatakan bahwa Likuiditas yang dihitung memakai Current Ratio mempunyai pengaruh dengan arah positif serta signifikan terhadap profitabilitas. Kondisi itu serupa dengan hasil yang diteliti oleh Rahma et al. (2016) yang membuktikan likuiditas berpengaruh dengan arah positif serta signifikan terhadap profitabilitas. Menurut Sartono (2014) likuiditas mengindikasikan perusahaan untuk melunasi hutang lancarnya dengan tepat waktu. Semakin naik nilai Current Ratio menandakan kemampuan perusahaan untuk melunasi hutang lancarnya semakin besar. Hal ini menunjukkan semakin liquid aset lancar milik suatu perusahaan maka semakin besar nilai profitabilitas yang didapatkan oleh perusahaan itu.

Variabel Leverage yang dihitung memakai Debt to Assets Ratio berdasarkan hasil yang diteliti bisa dinyatakan bahwa mempunyai pengaruh dengan arah positif serta tidak signifikan terhadap profitabilitas. Kondisi itu serupa dengan hasil yang telah diteliti oleh Felany dan Worokinasih (2018) yang membuktikan leverage berpengaruh dengan arah positif serta tidak signifikan terhadap profitabilitas. Leverage tidak signifikan terhadap profitabilitas dapat diartikan bahwa naik turunnya leverage tidak berkontribusi terhadap naik turunnya profitabilitas yang dihasilkan perusahaan. Menurut Kasmir (2013) Debt to Assets Ratio menunjukkan sejauh mana aktiva perusahaan di biayai dengan utang. Semakin tinggi Debt to Assets Ratio berarti utang yang dimiliki perusahaan lebih tinggi dibandingkan dengan aktiva yang dimiliki. Profitabilitas perusahaan diperoleh dari pendapatan atas pembelian konsumen terhadap produk yang dijual. Semakin tinggi konsumsi konsumen terhadap produk perusahaan maka dapat meningkatkan laba perusahaan. Dalam melakukan pembelian, konsumen tentu tidak mempertimbangkan tingkat utang maupun struktur keuangan yang dimiliki perusahaan, karena konsumen membeli produk didasarkan atas kebutuhan. Hal tersebut mengakibatkan tinggi rendahnya utang tidak berkontribusi terhadap profitabilitas perusahaan.

Variabel Aktivitas yang dihitung memakai Total Assets Turnover Ratio berdasarkan hasil yang telah diteliti dapat dinyatakan bahwa memiliki pengaruh dengan arah positif serta signifikan terhadap profitabilitas. Kondisi itu sesuai dengan hasil yang telah diteliti oleh Rahma et al. (2016) yang membuktikan aktivitas berpengaruh dengan arah positif dan signifikan terhadap profitabilitas. Menurut Hery (2015) aktivitas digunakan untuk mengukur tingkat efisiensi atas pemanfaatan sumber daya yang dimiliki perusahaan. Hasil riset ini sesuai dengan teori yang menjelaskan bahwa semakin naik Total Assets Turnover Ratio menandakan kenaikan pula pada profitabilitas. Kondisi tersebut menunjukkan bahwa manajemen sumber daya yang dimiliki perusahaan dari ketersediaan total aset cukup baik dan apabila digunakan untuk menunjang kegiatan penjualan maka akan menghasilkan profit. Dengan begitu semakin efisien pengelolaan aset perusahaan mampu meningkatkan profitabilitas perusahaan.

\section{Simpulan dan Saran Simpulan}

1. Likuiditas mampu memberikan partisipasi terhadap peningkatan profitabilitas pada perusahaan food and beverages yang tercatat di BEI periode 2015-2018. Keadaan itu menjelaskan semakin tinggi likuiditas disisi lain perusahaan akan mengalami kenaikan pula terhadap profitabilitasnya dan begitu juga sebaliknya.

2. Leverage tidak mampu memberikan kontribusi terhadap peningkatan profitabilitas pada perusahaan food and beverages yang tercatat di BEI periode 2015-2018. Keadaan itu menjelaskan bahwa naik turunnya leverage yang dimiliki perusahaan tidak memberikan kontribusi terhadap profitabilitas.

3. Aktivitas mampu memberikan kontribusi terhadap peningkatan profitabilitas pada perusahaan food and beverages yang tercatat di BEI periode 2015-2018. Hal tersebut menjelaskan semakin naik aktivitas disisi lain perusahaan akan mengalami kenaikan pula terhadap profitabilitasnya dan be- 
gitu juga sebaliknya.

\section{Saran}

1. Tingkat leverage yang dihitung memakai debt to assets ratio termasuk cukup tinggi dikarenakan hutang yang dimiliki perusahaan food and beverages lebih tinggi daripada aset yang dimiliki. Jika tingkat hutang cukup tinggi dan pihak perusahaan tidak memanfaatkan untuk menunjang kegiatan operasional maka perusahaan akan tetap membayar beban atas hutang tersebut sehingga tidak dapat mengoptimalkan profitabilitas. Maka dari itu pihak perusahaan sebaiknya dapat mendayagunakan hutang untuk menunjang kegiatan operasional sehingga dapat menghasilkan profitabilitas.

2. Bagi penelitian berikutnya yang akan melaksanakan riset dengan topik yang sama sebaiknya memakai variabel yang lebih beragam seperti pertumbuhan penjualan, ukuran perusahaan, dan sebagainya. Lalu, sampel yang dipakai tidak hanya perusahaan food and beverages saja melainkan dapat memakai sampel dari perusahaan lainnya yang terdaftar di BEI agar dapat menambah referensi serta membuat hasil riset lebih komprehensif.

\section{Referensi}

Brigham, E., \& Houston, J. (2013). Dasar-dasar manajemen keuangan. Edisi Kesebelas. Jakarta: Salemba Empat.

Cryer, \& Miller. (1994). Statistics for business data analysis and modeling. California: International Thomson Publishing.

Felany, I. A., \& Worokinasih, S. (2018). Pengaruh perputaran modal kerja, leverage, dan likuiditas terhadap profitabilitas (studi pada perusahaan sub sektor makanan dan minuman yang terdaftar di bursa efek indonesia pada tahun 2012-2016). Jurnal Administrasi Bisnis (JAB), 58(2), 119128.

Hery. (2015). Analisis laporan keuangan pendekatan rasio keuangan. Yogyakarta: CAPS.

Horne, V., \& Wachowicz, J. (2013). Prinsip-prinsip manajemen keuangan. Edisi Ketiga Belas. Jakarta: Salemba Empat.

Kasmir. (2013). Analisis laporan keuangan. Edisi Keenam. Jakarta: Raja Grafindo Persada.

Marusya, P., \& Magantar, M. (2016). Pengaruh struktur modal terhadap profitabilitas pada perusahaan tobacco manufacturers yang terdaftar di bursa efek indonesia (BEI) periode 2008-2015. Jurnal Berkala Ilmiah Efisiensi, 16(3), 484-492.

Munawir, S. (2014). Analisa laporan keuangan. Edisi Ketujuh Belas. Yogyakarta: Liberty.

Rahma, A. M., Cipta, W., \& Yudiaatmaja, F. (2016). Pengaruh likuiditas, solvabilitas, dan aktivitas terhadap profitabilitas pada perusahaan otomotif yang terdaftar di bursa efek indonesia periode 2012-2014. E-Journal Bisma Universitas Pendidikan Ganesha Jurusan Manajemen, 4(1). Retrieved from https://ejournal.undiksha.ac.id/index.php/JMI/article/view/6668/4531

Riyanto, B. (2013). Dasar-dasar pembelanjaan perusahaan. Edisi Keempat. Yogyakarta: BPFE.

Sartono, A. (2014). Manajemen keuangan: Teori dan aplikasi. Edisi Keempat. Yogyakarta: BPFE.

Sekaran, U. (2006). Metodologi penelitian untuk bisnis. Edisi Keempat. Jakarta: Salemba Empat.

Syamsuddin, L. (2016). Manajemen keuangan perusahaan: Konsep aplikasi dalam perencanaan, pengawasan, dan pengambilan keputusan. Jakarta: Raja Grafindo Persada. 